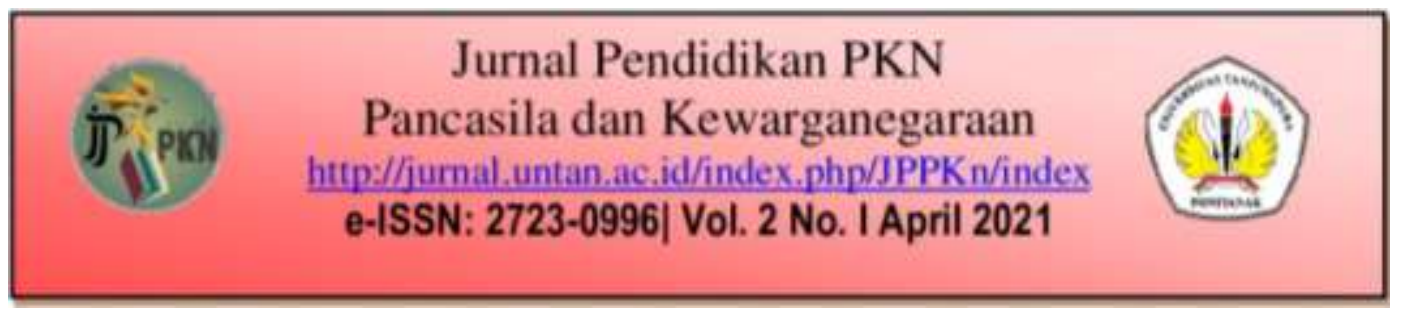

\title{
PENELITIAN TINDAKAN KELAS DALAM PENDIDIKAN KEWARGANEGARAAN
}

\author{
T Heru Nurgiansah ${ }^{1 *}$, Febri Fajar Pratama ${ }^{2}$, Aulia Sholichah Iman \\ Nurchotimah $^{3}$ \\ ${ }^{1}$ Universitas PGRI Yogyakarta, Yogyakarta, Indonesia \\ ${ }^{2}$ Universitas Perjuangan, Tasikmalaya, Indonesia \\ ${ }^{3}$ Institut Agama Islam Negeri Syekh Nurjati, Cirebon, Indonesia
}

*nurgiansah@upy.ac.id

\begin{abstract}
ABSTRAK
Penelitian Tindakan Kelas dilakukan untuk menyelesaikan permasalahan belajar. Guru yang profesional harus mampu mengaplikasikan beragam model dan media pembelajaran. Mayoritas siswa menganggap mata pelajaran Pendidikan Kewarganegaraan adalah yang paling membosankan. Tujuan penelitian ini adalah untuk mengetahui keberhasilan penelitian tindakan kelas yang dilakukan oleh guru Pendidikan Kewarganegaraan. Penelitian ini menggunakan metode kualitatif. Pengumpulan data menggunakan observasi, wawancara, dokumentasi, literasi. Hasil penelitian ini menunjukan bahwa guru-guru Pendidikan Kewarganegaraan yang melaksanakan penelitian tindakan kelas berhasil menyelesaikan permasalahan belajar seperti rendahnya motivasi dan prestasi siswa sekaligus memastikan bahwa penelitian tindakan kelas adalah solusi konkrit dalam meyelesaikan permasalahan belajar khususnya pada mata pelajaran pendidikan kewarganegaraan.
\end{abstract}

Kata Kunci: Penelitian Tindakan Kelas, Pendidikan Kewarganegaraan

\section{ABSTRACT}

Class action research is conducted to solve learning problems. Professional teachers must be able to apply various models and learning media. The majority of students consider civic education subjects to be the most tedious. The purpose of this research is to know the successful research of class actions conducted by the teachers of citizenship education. This research uses qualitative methods. Data collection using observations, interviews, documentation, literacy. The results of this research show that the teachers of citizenship education who conduct class action research successfully solve learning problems such as low motivation and student achievement while ensuring that class action research is a concrete solution in the course of learning problems especially in citizenship education subjects

Keywords: classroom action Research, citizenship education 


\section{PENDAHULUAN}

Belajar sepanjang hayat, itulah slogan yang terus menerus didegungkan banyak kalangan terutama praktisi akademis. Belajar dalam konteks pendidikan berarti adanya perubahan ke arah yang lebih baik dalam hal pengetahuan dan perilaku. Pendidikan adalah investasi jangka panjang (Surbakti, 2018). Meskipun terasa pahit di awal dengan bersusah payah akan tetapi buahnya nanti terasa manis. Selain itu pendidikan memiliki peran yang sangat penting dalam upaya peningkatan sumber daya manusia yang lebih baik (Fidarto, 2019). Dengan sumber daya manusia yang semakin baik dalam hal ini guru maka dunia pendidikan kita akan semakin maju dan mampu bersaing dengan negara manapun dalam pergaulan internasional.

Kegiatan belajar mengajar seperti kegiatan rutinitas (Suwastana, 2016). Baik guru maupun siswa selama lima sampai enam hari berada di lingkungan sekolah yang sama dan waktu yang sama pula. Rutinitas ini lambat laun akan membentuk suatu kebiasaan yang positif, seperti kedisiplinan dan rasa tangung jawab. Teori Tabula Rasa atau kertas kosong menjabarkan bahwa setiap manusia yang terlahir tidak mempunyai pengetahuan apapun. Namun setelah mengenyam rutinitas belajar, kertas kosong tersebut menjadi penuh makna. Dengan demikian rutinitas belajar perlu dipertahankan bahkan ditingkatkan. Belajar juga merupakan kegiatan yang harus mengalami sendiri (Subagyo, 2018). Hal ini akan membentuk pribadi masing-masing yang berbeda hasil dari pengalamannya terutama di lingkungan sekolah.

Salah satu mata pelajaran di sekolah yang diajarkan adalah mata pelajaran Pendidikan Kewarganegaraan atau disingkat PKn. Pkn merupakan salah satu mata pelajaran yang wajib dibelajarkan (Mardikayasa et al., 2015). Hal ini sesuai dengan isi dari Undang-Undang Sistem Pendidikan Nasional nomor 20 tahun 2003 yang mewajibkan mata pelajaran PKn diajarkan di semua jenjang pendidikan formal mulai dari pendidikan dasar bahkan sampai perguruan tinggi di seluruh wilayah nusantara.

Selain itu yang menjadi ciri khas dari Pendidikan Kewarganegaraan adalah sebagai salah satu mata pelajaran yang pengusaannya menuntut siswa menghafal materi (Lukiyah, 2017). Materi-materi tersebut diantaranya aturan perundang-undangan, sosial politik, hukum ketatanegaraan, budaya dan ekonomi. Dengan materi yang sedemikian banyaknya tidak heran jika timbul permasalahan seperti rasa bosan yang berimbas pada minat belajar siswa, bahkan tak sedikit siswa yang 
menganggap bahwa PKn adalah pelajaran yang sulit saking banyaknya materi yang harus dihapal sehingga berimbas pada prestasi belajar siswa yang rendah. Padahal PKn sebagai pendidikan nilai dan moral adalah mata pelajaran yang harus dipraktekan dalam kehidupan sehari-hari tidak hanya sebagai hapalan materi yang cara penyampaiannya melalui indoktrinisasi. mata pelajaran PKn sarat nilai dan norma sehingga ada asumsi mata pelajaran ini kurang menarik dan sering bersifat indoktrinasi (Rokanah, 2015).

Selain masalah minat belajar dan prestasi siswa dalam hal akademik khususnya pada mata pelajaran PKn, masalah yang terjadi di lapangan adalah motivasi siswa dalam pembelajaran PKn masih kurang (Farida Hasan Rahmaibu, Farid Ahmadi, 2017). Motivasi belajar siswa yang yang rendah ini bukan tanpa alasan. Selain materinya yang banyak seperti yang telah disampaikan sebelumnya, peran guru dalam penyampaian materinya pun perlu mendapat sorotan karena disinyalir sebagai salah satu faktor penyebabnya. Untuk itu diperlukan suatu cara agar siswa tertarik pada mata pelajaran Pendidikan Kewarganegaraan (Syaparuddin et al., 2020). In improving the learning of PKn, we need student learning interaction (Nurgiansah, 2020). Artinya bahwa diperlukan interaksi antara guru dan siswa untuk meningkatkan kualitas pembelajaran khususnya pada mata pelajaran PKn.

Guru memiliki peran yang sangat strategis dalam proses pembelajaran (Yulianingrum, 2014). Peran strategis itu diantaranya guru sebagai motivator yang memberikan motivasi dan semangat kepada siswanya untuk mau belajar dengan sungguh-sungguh. Siswa akan termotivasi jika melihat gurunya memiliki motivasi yang besar dalam mengajar guna mencerdaskan anak didik bangsa. Selain perannya sebagai motivator, guru pun harus menjadi fasilitator dalam artian memfasilitasi sarana dan prasana pembelajaran agar memiliki suasana yang baru dan menyenangkan seperti penggunakan teknologi. Perkembangan zaman mengharuskan guru untuk terus berkembang dan meningkatkan kompetensinya (Nurgiansah \& Pringgowijoyo, 2020). Tidak hanya kompetensi pedagogiknya saja yang perlu ditingkatkan, tetapi kompetensi profesionalismenya pun harus terus diasah agar mampu menyesuaikan diri seiring perkembangan zaman dan perubahan karakteristik siswa dari tahun ke tahun. Selain itu guru juga bertugas sebagai pelatih dan pembimbing yang berarti memberikan keterampilan kepada siswa agar dapat bersaing (Nurgiansah \& Sukmawati, 2020). 
Seorang guru diharapkan mampu untuk bersikap fleksibel dalam mengatasi beragam persoalan (Nurgiansah, 2019). Persoalan dalam pembelajaran perlu dicari solusinya agar masalah dalam pembelajaran tidak terjadi terus menerus. Salah satu upaya yang bisa dilakukan oleh guru dalam menyelesaikan permasalahan belajar adalah melaksanakan Penelitian Tindakan Kelas. Penelitian tindakan kelas yang lazimnya disingkat PTK adalah kegiatan mencermati suatu objek dengan menggunakan aturan-aturan tertentu untuk memperoleh informasi yang bermanfaat dan bertujuan untuk memperbaiki atau meningkatkan mutu praktek pembelajaran (Noviana \& Huda, 2018). Peningkatan mutu belajar bisa dilakukan manakala guru pun melakukan evaluasi terhadap dirinya sendiri apakah materi yang disampaikan sudah bisa dicerna oleh siswa seluruhnya atau justru baru sebagaian bahkan tidak ada sama sekali. Semakin bagus mutu belajar dan mutu gurunya maka akan berimplikasi pada mutu sekolah khususnya dan mutu pendidikan pada umumnya.

Tujuan PTK sendiri adalah untuk meningkatkan dan/atau memperbaiki praktik pembelajaran di sekolah (Sari, 2014). Perbaikan pembelajaran khususnya pada mata pelajaran PKn mutlak harus dilaksanakan salah satunya dengan PTK. Selain itu Penelitian Tindakan Kelas juga perlu ada panduan dan metodologi yang terarah (Susanti et al., 2015). Hal ini harus dilakukan agar pelaksanaan PTK tidak serta merta sebagai penggugur kewajiban saja akan tetapi PTK dijadikan kebutuhan guru dan siswa. Panduan dalam PTK dapat diberikan pada guru melalui pendidikan dan pelatihan-pelatihan yang dilaksanakan lembaga kredibel atau oleh orang orang yang ahli dibidangnya.

Namun demikian para guru menganggap melakukan PTK adalah pekerjaan yang sangat rumit dan sulit (Hodriani, 2015). Kesulitan ini didasari karena guru bingung dalam memilih metode dan media pembelajaran yang pas dan tepat dengan materi yang akan disampaikan. Sebagai contoh dalam materi PKn ada materi tentang sistem hukum dan peradilan nasional. Jika materi ini disampaikan dengan metode ceramah saja maka akan membuat siswa merasa bosan. Tapi jika menggunakan metode yang tepat misalnya Role Playing atau bermain peran, niscahya siswa akan bersemangat karena dengan metode ini siswa akan terlibat langsung dalam materi misalnya siswa berperan sebagai aparat kepolisian, hakim, jaksa atau pengacara ketimbang guru hanya menjelaskan pengertian-pengertian dan tugas dari para aparat penegakan hukum. Selain itu guru juga perlu mengembangkan media dan model pembelajaran. Media pembelajaran yang menarik dan menyenangkan 
akan mampu menghilangkan rasa bosan dalam pembelajaran sehingga pembelajaran menjadi optimal (Dewantara \& Nurgiansah, 2021).

Berdasarkan persoalan diatas maka peneliti berasumsi bahwa dalam pembelajaran pendidikan kewarganegaraan di sekolah masih terdapat banyak permasalahan dan diperlukan solusi untuk menyelesaikannya dengan cara melaksanakan penelitian tindakan kelas yang dilakukan oleh guru. Teachers need to plan learning better (Nurgiansah et al., 2020). Artinya guru perlu mempersiapkan pembelajaran lebih baik dari pertemuanpertemuan sebelumnya.

Dengan demikian, fokus penelitian ini adalah upaya pengembangan penelitian tindakan kelas yang mutlak dilakukan oleh guru untuk menyelesikan segala persoalan belajar. Penelitian tindakan kelas ini menjadi sebuah kebutuhan yang sangat mendesak terutama di era globalisasi saat ini.

\section{METODE PENELITIAN}

Metode penelitian yang digunakan dalam penulisan artikel ini adalah metode kualitatif. Penelitian kualitatif adalah penelitian yang bersifat menggambarkan kenyataan (Taufiqillah, 2006). Dengan menggunakan sebuah pendekatan kualitatif, peneliti bisa fokus pada perhatian dan juga kejadian yang alamiah (Nurgiansah \& Widyastuti, 2020). Dengan metode ini permasalahan dapat tergambarkan semurnimurninya sehingga memudahkan peneliti untuk menggambarkan permasalahan dan solusinya secara detail.

Tehnik pengumpulan data dilakukan dengan cara wawancara kepada guru-guru mata pelajaran PKn pada jenjang sekolah menengah pertama maupun sekolah menengah atas. Wawancara pun dilakukan kepada beberapa siswa untuk mengetahui permasalahan sebenarnya yang dirasakan langsung oleh siswa. Jika menceritakan ke gurunya merasa sungkan bahkan takut, lain halnya kepada peneliti para siswa mencurahkan semua isi hati yang menjadi permasalahan dalam pembelajaran PKn. Selain teknik wawancara, peneliti juga melaksanakan pengamatan langsung di salah satu sekolah di Yogyakarta mengenai pelaksanaan PTK pada mata pelajaran PKn. Teknik selanjutnya adalah domukentasi dan literasi. Literasi berisi kegiatan mencari referensi mengenai artikel terkait 


\section{HASIL DAN PEMBAHASAN}

Penelitian Tindakan Kelas merupakan solusi konkrit dan tepat dalam menyelesaikan permasalahan belajar PKn. Secara umum dalam PTK seorang guru harus menentukan model pembelajaran yang akan digunakan. Beragam model pembelajaran yang bisa digunakan diantaranya, Jigsaw, Picture and Picture, Problem Based Learning. Pemilihan model pembelajaran dalam PTK harus disesuaikan dengan materi yang akan disampaikan dan disesuaikan dengan permasalahan yang akan dicari jalan keluarnya.

PTK sendiri biasanya dilaksanakan beberapa siklus sampai permasalahan belajar benear-benar dapat diatasi dengan baik. PTK yang berhasil ditandai dengan adanya perubahan dan peningkatan kualitas belajar. Jika pembelajaran PKn dirasakan begitu-begitu saja berarti pelaksaan PTK belum optimal dan perlu penambahan siklus bahkan dengan mengganti model pembelajaran yang lebih relavan.

Dalam pembelajaran di kelas, guru harus menyiapkan perencanaan yang matang agar pelaksanaan pembelajaran menjadi efektif dan menghasilkan penilaian yang sempurna. Dalam perencanaan, guru mempersiapkan silabus, RPP, dan materi ajar. Persiapan ini bisa dilakukan sebelum ajaran baru dimulai agar bisa mengantisipasi kemungkinan masalah yang terjadi. Kemudian dalam pelaksanaan pembelajaran PKn, guru membagi ke dalam 3 segmen, yakni kegiatan pendahuluan seperti mengucapkan salam, menanyakan kabar, mempersiapkan absensi siswa, dan memimpin berdoa. Lalu kegiatan inti yang ditandai dengan pembelajaran dua arah, guru memberikan stimulus berupa pertanyaa-pertanyaan dan siswa memberikan respon atas stimulus yang diberikan oleh guru. Dan ada semgem penutup berisi evaluasi guru terhadap materi yang telah disampaikan. Evaluasi ini bisa berupa tanya jawab, pemberian tugas, atau pengerjaan lembar kerja siswa.

Hal terpenting dalam tahap pelaksanaan pembelajaran adalah pemilihan metode dan media yang tepat. Media pembelajaran dibuat sedemikian menarik agar berhasil memancing fokus siswa. Media pembelajaran yang menarik untuk dilihat dan enak didengar akan menambah motivasi belajar siswa, partisipasi siswa, dan keaktipan siswa. Indikator dari siswa yang termotivasi dapat dilihat dari jumlah kehadiran di kelas saat pelajaran PKn dan ketepatan waktu dalam memasuki kelas. Jika siswa kebanyakan terlambat masuk kelas dapat dipastikan siswa berusaha menghindar mata pelajaran PKn atau sekedar mengulur-ulur waktu. Dalam hal keaktifan siswa, dapat terlihat bagaimana respon dan 
perilaku siswa seperti menjawab salam, mengajukan pertanyaan atau sekedar memberikan pendapat.

Beberapa masalah belajar PKn yang dialami siswa berdasarkan hasil wawancara menyebutkan bahwa siswa mengalami penurunan motivasi belajar karena rasa jenuh yang dihasilkan dari banyaknya materi. Lain halnya dengan hasil wawancara guru, mayoritas menjawab bahwa permasalahan yang paling umum adalah prestasi belajar hal ini terlihat dari hasil ulangan harian atau ujian akhir semester yang dilaksanakan menunjukan nilai PKn siswa berada di bawah KKM atau kriteria ketuntasan minimal.

Jika dilhat dari karakteristik PKn sendiri, mata pelajaran ini sangat berbeda dengan denga mata pelajaran lainnya, Adapun aspek-aspek kompetensi dalam Pendidikan Kewarganegaraan sebagai berikut:

a. Pengetahuan Kewarganegaraan (Civic Knowledge). Menyangkut kemampuan kewarganegaraan akademik-keilmuan yang dikembangkan dari berbagai teori atau konsep politik, hukum, dan moral. Dengan demikian, mata pelajaran PKn merupakan bidang kajian multidisipliner. Secara terperinci materi pengetahuan kewarganegaraan meliputi pengetahuan tentang hak dan tanggung jawab warga negara, hak asasi manusia, prinsip-prinsip dan proses demokrasi, lembaga pemerintah dan non pemerintah, identitas nasional, pemerintah berdasarkan hukum dan peradilan yang bebas dan tidak memihak, konstitusi, serta nilai-nilai dan norma-norma dalam masyarakat. Pendidikan kewarganegaraan memuat tentang pengetahuan kewarganegaraan yang berbasis kepada ilmu politik, hukum, dan kewarganegaraan. Sehingga pendidikan kewarganegaraan menyajikan sejumlah fakta, konsep, generalisasi, dan teori-teori yang dikembangkan dari ilmu politik, hukum, dan kewarganegaraan. Pendidikan kewarganegaraan hendaknya memperhatikan konsepkonsep kunci yang dikembangkan lebih lanjut dalam generalisasi dan teori.

b. Keterampilan Kewarganegaraan (Civic Skills). Keterampilan kewarganegaraan merupakan keterampilan yang dikembangkan dari pengetahuan kewarganegaraan, agar pengetahuan yang diperoleh menjadi sesuatu yang bermakna dan bermanfaat bagi dirinya sendiri maupun orang lain, karena dapat dimanfaatkan dalam menghadapi persoalan-persoalan dalam kehidupan berbangsa dan bernegara. Keterampilan kewarganegaraan meliputi kemampuan intelektual (intellectual skills) dan keterampilan berpartisipasi (participatory skills) 
dalam kehidupan berbangsa dan bernegara. Contoh keterampilan intelektual adalah keterampilan dalam merespon berbagai persoalan politik, misalnya merancang dialog dengan DPRD. Contoh keterampilan berpartisipasi adalah keterampilan menggunakan hak dan kewajiban di bidang hukum, misalnya melapor kepada polisi atas terjadinya kejahatan yang diketahui. Rincian keterampilan kewarganegaraan dapat dilihat pada tabel di bawah ini:

Tabel 2.1

Keterampilan Kewarganegaraan

\begin{tabular}{|c|c|}
\hline Keterampilan Intelektual & Keterampilan Partisipasi \\
\hline $\begin{array}{l}\text { 1. Mengidentifikasi } \\
\text { (menandai/ } \\
\text { menunjukan) } \\
\text { dibedakan menjadi } \\
\text { keterampilan: } \\
\text { - Membedakan } \\
\text { - Mengelompokan/ } \\
\text { mengklasifikasikan } \\
\text { - Menentukan bahwa } \\
\text { sesuatu itu asli } \\
\text { 2. Menggambarkan } \\
\text { (mmberikan uraian/ } \\
\text { ilustrasi) misalnya } \\
\text { tentang: } \\
\text { - Proses } \\
\text { - Lembaga } \\
\text { - Fungsi } \\
\text { - Alat } \\
\text { - Tujuan } \\
\text { - Kualitas } \\
\text { 3. Menjelaskan } \\
\text { (mengklarifikasi/ } \\
\text { menafsirkan) misalnya } \\
\text { tentang: } \\
\text { - Sebab-sebab } \\
\text { terjadinya suatu } \\
\text { - peristiwa } \\
\text { - Makna dan }\end{array}$ & $\begin{array}{l}\text { 1. Berinteraksi (termasuk } \\
\text { berkomunikasi) } \\
\text { terhadap objek yang } \\
\text { berkaitan dengan } \\
\text { masalah-masalah } \\
\text { publik, yang termasuk } \\
\text { dalam keterampilan } \\
\text { ini, antara lain: } \\
\text { - Bertanya, } \\
\text { menjawab, } \\
\text { berdiskusi dengan } \\
\text { sopan santun } \\
\text { - Menjelaskan } \\
\text { artikulasi } \\
\text { kepentingan } \\
\text { - Membangun koalisi, } \\
\text { negosiasi, } \\
\text { kompromi } \\
\text { - Mengelola konflik } \\
\text { secara damai } \\
\text { - Mencari konsensus } \\
\text { Memantau/ memonitor } \\
\text { masalah politik dan } \\
\text { pemerintahan } \\
\text { terutama dalam } \\
\text { penanganan persoalan- } \\
\text { persoalan publik. Yang } \\
\text { termasuk keterampilan }\end{array}$ \\
\hline
\end{tabular}




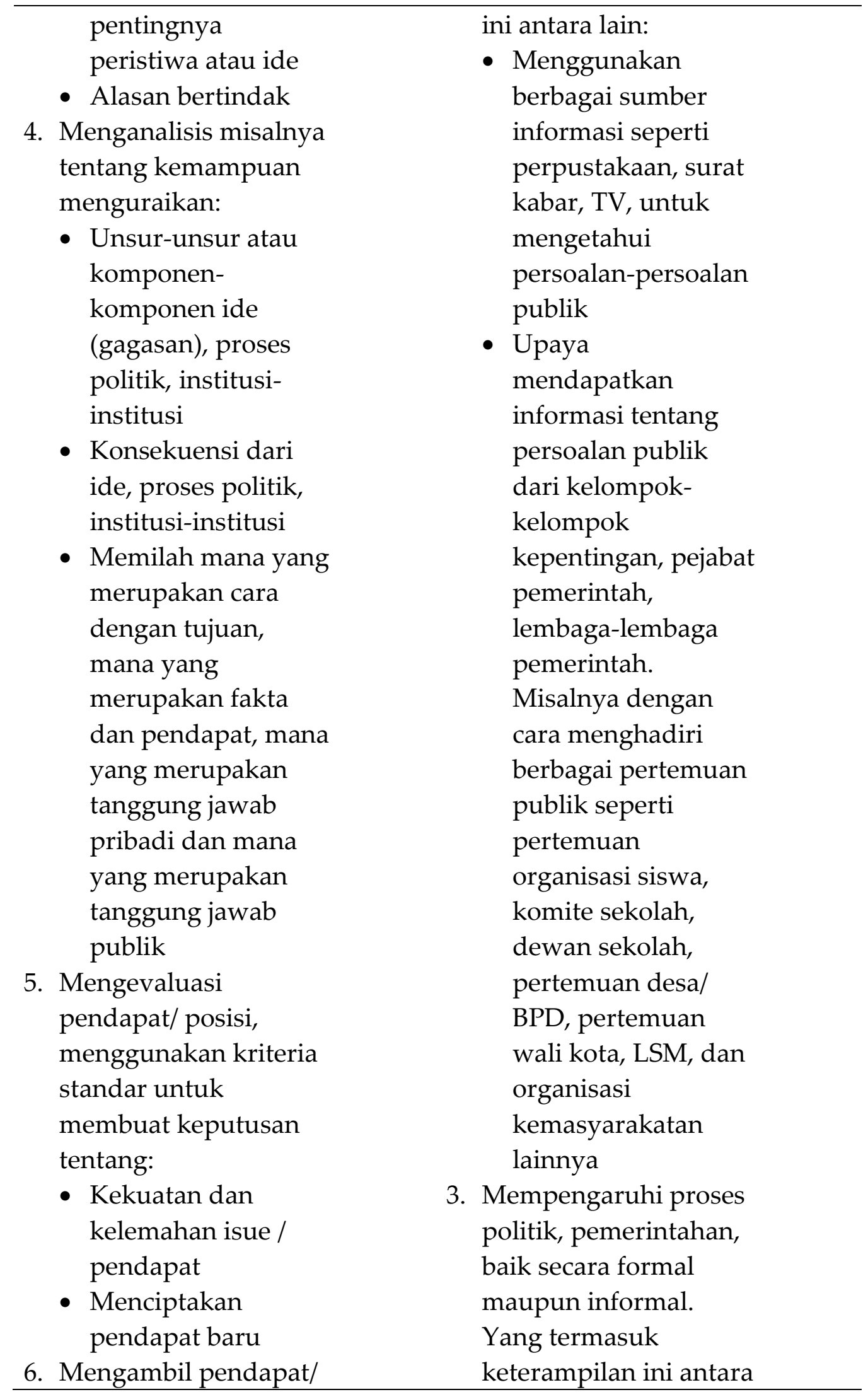


posisi:

- Dari hasil seleksi berbagai posisi

- Membuat pilihan baru

7. Mempertahankan pendapat/ posisi:

- Mengemukakan argumentasi berdasarkan asumsi atas posisi yang dipertahankan/ diambil/ dibela

- Merespon posisi yang tidak disepakati lain:

- Melakukan simulasi tentang kegiatan kampanye, pemilu, dengar pendapat di DPR/ DPRD, pertemuan wali kota, lobby, peradilan

- Memberikan suara dalam suatu pemilihan

- Membuat petisi

- Melakukan pembicaraan/ memberi kesaksian dihadapan lembaga publik

- Bergabung atau bekerja dalam lembaga advokasi untuk memperjuangkan tujuan bersama atau pihak lain

- Meminta atau menyediakan diri untuk menduduki jabatan tertentu

Sumber: diolah dari Center for civic education (1994), National standard for civics and government, p.p. 1-5: 127-135

c. Watak Kepribadian Kewarganegaraan (Civic Disposition). Watak Keperibadian Kewarganegaraan sesungguhnya merupkan dimensi yang paling substantif dan essensial dalam mata pelajaran Pendidikan Kewarganegaraan dapat dipandang sebagai "muara" dari pengembangan kedua dimensi sebelumnya. Dengan memperhatikan visi, misi dan tujuan mata pelajaran ini ditandai dengan penekanan 
pada dimensi watak, karakter, sikap dan potensi lain yang bersifat afektif.

Berdasarkan temuan pembahasan di atas, maka kita dapat meyakini bahwa penelitian tindakan kelas merupakan formula yang tepat dalam mengatasi permasalahan belajar khususnya pada mata pelajaran Pendidikan Kewarganegaraan

\section{KESIMPULAN}

Berdasarkan paparan diatas dapat disimpulakan bahwa Penelitian Tindakan Kelas mempunyai peranan penting dalam peningkatan mutu dan penyelesaian masalah pembelajaran Pendidikan Kewarganegaraan. Beberapa masalah pembelajaran PKn diantaranya rendahnya motivasi belajar, prestasi siswa, partisipasi di kelas, dan keaktifan belajar. Semua permasalahan ini dapat diselesaikan oleh guru dengan melaksanakan PTK. Secara umum pelaksanakan pembelajaran PKn di sekolah harus terdiri dari tiga komponen yakni perencanaan yang matang, pelaksaan, dan penilaian atau evaluasi. Ketiga komponen ini harus terus dilaksanakan secara berkesinambungan agar menjadi kebiasaan yang bermanfaat bagi dunia pendidikan.

\section{DAFTAR PUSTAKA}

Dewantara, J. A., \& Nurgiansah, T. H. (2021). Efektivitas Pembelajaran Daring di Masa Covid-19 Bagi Mahasiswa Universitas PGRI Yogyakarta. Jurnal Basicedu: Research $\mathcal{E}$ Learning in Elementary Education, 5(1), 367-375.

Farida Hasan Rahmaibu, Farid Ahmadi, F. D. P. (2017). Pengembangan Media Pembelajaran Menggunakan Adobe Flash Untuk Meningkatkan Hasil Belajar PKn. Jurnal Kreatif: Jurnal Kependidikan Dasar, 7(1).

Fidarto, M. (2019). Penerapan Model Pembelajaran Kooperatif Tipe Student Teams Achievement Division (STAD) Untuk Meningkatkan Hasil Belajar PKn Pada Materi Berorganisasi di Kelas V SD Negeri 09 Kendari Barat. Jurnal Ilmiah Pembelajaran Sekolah Dasar, 1(1), 69-74.

Hodriani. (2015). Pembinaan Sekolah SMK Untuk Meningkatkan 
Profesionalisme Guru PKn Melalui PTK dan Publikasi Ilmiah. PPKn Universitas Negeri Medan.

Lukiyah, L. (2017). Efektivitas Model Pembelajaran Numbered Head Together (NHT) terhadap Peningkatan Hasil Belajar Siswa dalam Pembelajaran PKn ( Penelitian Tindakan Kelas) pada Siswa Kelas VI SDN Randuagung 05. Jurnal PTK Dan Pendidikan, 3(1), 9-15. https://doi.org/10.18592/ptk.v3i1.1058

Mardikayasa, I. M., Wiyasa, I. K. N., \& Asri, I. G. A. A. S. (2015). Penerapan Mind Mapping Dalam Pendekatan Saintifik Untuk Meningkatkan Hasil Belajar Pkn Dan Sikap Sosial Tema Cita-Citaku Pada Siswa Kelas Iva Sd Negeri 29 Pemecutan. E-Journal PGSD Universitas Pendidikan Ganesha, 3(1).

Noviana, E., \& Huda, M. N. (2018). Penerapan Model Pembelajaran Kooperatif Tipe Stad Untuk Meningkatkan Hasil Belajar Pkn Siswa Kelas Iv Sd Negeri 79 Pekanbaru. Primary: Jurnal Pendidikan Guru Sekolah Dasar, 7(2), 204-210. https://doi.org/10.33578/jpfkip.v7i2.6287

Nurgiansah, T. H. (2019). Pemutakhiran Kurikulum Pendidikan Kewarganegaraan di Era Revolusi Industri 4.0. Prosiding Seminar Kewarganegaraan Universitas Negeri Medan, 1(1), 95-102.

Nurgiansah, T. H. (2020). Build An Attitude of Nationalism Students At SDN 7 Kadipaten With The Method of Discusion In The Subject PPKn. Jurnal Serunai Pendidikan Pancasila Dan Kewarganegaraan STKIP Budi Daya Binjai, 9(1), 1-11.

Nurgiansah, T. H., Dewantara, J. A., \& Rachman, F. (2020). The Implementation of Character Education in the Civics Education Syllabus at SMA Negeri 1 Sleman. Jurnal Etika Demokrasi, 5(2), 110121.

Nurgiansah, T. H., \& Pringgowijoyo, Y. (2020). Pelatihan Penggunaan Model Pembelajaran Jurisprudensial Pada Guru Di KB TK Surya Marta Yogyakarta. KUAT: Keuangan Umum Dan Akuntansi Terapan. PKNSTAN, 2(1).

Nurgiansah, T. H., \& Sukmawati. (2020). Tantangan Guru Pendidikan Kewarganegaraan Di Masa Adaptasi Kebiasaan Baru. Jurpis: Jurnal Pendidikan Ilmu Sosial, 17(2), 139-149.

Nurgiansah, T. H., \& Widyastuti, T. M. (2020). Membangun Kesadaran Hukum Mahasiswa PPKn UPY Dalam Berlalu Lintas. Civic Edu: Jurnal 
Pendidikan Kewarganegaraan Universitas Pasundan, 2(2), 97-102. https://doi.org/10.1017/CBO9781107415324.004

Rokanah. (2015). Meningkatkan Prestasi Belajar PKn Melalui Metode Pemberian Tugas Daur Ulang. Jurnal Media Didaktika, 1(1), 31-37.

Sari, H. N. M. (2014). Implementasi Metode Vak (Visual Auditori Kinestetik) Guna Meningkatakan Motivasi Belajar Siswa Mata Pelajaran Pkn Materi Penegakan Ham ( Kelas X Bina Prestasi 2 Di Man 2 Ponorogo Tahun 2013 / 2014). Universitas Muhammadiyah Ponorogo.

Subagyo. (2018). Peningkatan Hasil Belajar PKn melalui Model Kooperatif tipe Two Stay Two Stray. Jurnal Pendidikan: Riset \& Konseptual, 2(1), 103-107.

Surbakti, K. (2018). Upaya Meningkatkan Hasil Belajar Pkn Siswa Dengan Menggunakan Model Talking Stick materi sistem pemerintahan $\begin{array}{llll}\text { pusat. Jurnal Tematik, } & 7(1), & 166-171 .\end{array}$ file:///C:/Users/7/Downloads/10386-22291-1-SM.pdf

Susanti, E., Dicki, D., Dosen, H., Tarbiyah, F., Uin, K., Syarif, S., \& Riau, K. (2015). Peningkatan Kompetensi Guru Melalui Penerapan Penelitian Tindakan Kelas (Ptk) Dalam Pendidikan Islam. POTENSIA: Jurnal Kependidikan Islam, 14(1), 151-174.

Suwastana, I. W. (2016). Penerapan pembelajaran melalui model kooperatif numbered heads together siswa kelas V SDN No 1 Tonggolobibi untuk meningkatkan prestasi belajar PKn. Jurnal Kreatif Tadulako Online, 4(1), 119-135. http://jurnal.untad.ac.id/jurnal/index.php/JKTO/article/viewFile/3281/ 2324

Syaparuddin, S., Elihami, E., \& Enrekang, M. (2020). Peningkatan Motivasi Belajar Siswa Melalui Video Pada Pembelajaran PKn di Sekolah Paket C. Jurnal Edukasi Nonformal, 1(1), 187-200. file:///C:/Users/ACER/AppData/Local/Temp/318-Article Text-621-110-20200124-2.pdf

Taufiqillah, T. (2006). Penggunaan Media Gambar Dengan Pembelajaran Kooperatif Tipe Stad Untuk Meningkatkan Hasil Belajar Siswa Pada Mata Pelajaran Pkn Kelas Iv Sd Hang Tuah 11 Sidoarjo. PGSD FIP Universitas Negeri Surabaya, 1-5.

Yulianingrum, K. (2014). Kompetensi Profesionalisme Guru Pendidikan 
Jurnal Pendidikan Pancasila dan Kewarganegaraan

Volume II Nomor 1 (April) 2021

Kewarganegaraan Ditinjau Dari Latar Belakang Pendidikan (Studi Kasus Guru PKn di SMP Muhammadiyah 1 Surakarta). Fakultas Keguruan Dan Ilmu Pendidikan Universitas Muhammadiyah Surakarta. 